\title{
Temporal variability of fish larvae assemblages: influence of natural and anthropogenic disturbances
}

\author{
David A. Reynalte-Tataje ${ }^{1}$, Evoy Zaniboni-Filho ${ }^{1}$, Andrea Bialetzki², \\ Angelo A. Agostinho ${ }^{2}$
}

Natural and induced disturbances greatly influence the temporal distribution of ichthyoplankton abundance. This study assesses and compares the temporal variability of fish larvae assemblages in controlled and free environments to determine the influence of environment variables on the main taxa in these systems. The study was conducted at the Chapecó (without dam impact) and Ligeiro (with dam impact) river mouths, which are located in the upper Uruguay River. Samples were made between October 2001 and March 2004 during three reproductive periods. The larvae assemblages were composed of small and medium-sized Characiformes and Siluriformes. The variation in the distribution of larvae was mainly temporal $(>85 \%)$. When the three reproductive periods were compared, it was observed in the second period, characterized by a larger water flow and a lower temperature, that there was a reduction in abundance, a lower number of taxa, an absence of stages in post-flexion and a high dissimilarity in larvae assemblage structure. In general, the environmental variables of water flow and temperature most influenced the distribution of egg and larvae abundance. In the studied area, a smaller temporal variability was observed in the structure of larvae assemblages at the sampling sites in the Chapecó River mouth than in in the Ligeiro River mouth under the influence of dams.

Os distúrbios naturais e induzidos têm notável influência na distribuição temporal da abundância do ictioplâncton. Este estudo visa avaliar e comparar a variabilidade temporal das assembleias de larvas de peixes, entre ambientes regulados e ambientes livres, bem como, determinar a influência das variáveis ambientais sobre os principais táxons presentes nestes ambientes. O trabalho foi conduzido na foz dos rios Chapecó (sem impacto de barramento) e Ligeiro (impactado por barragens), ambos localizados no alto rio Uruguai. As coletas foram realizadas entre outubro de 2001 e março de 2004 durante três períodos reprodutivos. As assembléias de larvas estiveram compostas principalmente por Characiformes e Siluriformes de pequeno e médio porte. A variação na distribuição de larvas foi principalmente temporal ( $>85 \%)$. Quando comparados os três períodos reprodutivos, foi observado que no segundo período, caracterizado por uma maior vazão da água e menor temperatura, houve redução na abundância, menor número de táxons, ausência de estágios em pós-flexão e elevada dissimilaridade na estrutura da assembléia de larvas. Em geral, as variáveis ambientais vazão e temperatura da água foram as que mais influenciaram a distribuição da abundância de ovos e larvas. Nos ambientes estudados, foi observado que existe uma menor variabilidade temporal na estrutura das assembléias de larvas das estações presentes na foz do rio Chapecó do que naquelas presentes na foz do rio Ligeiro, o qual esta sob influência dos barramentos.

Key words: Dams, Environmental variables, Ichthyoplankton, Reproduction.

\section{Introduction}

A central theme in community ecology is the study of abundance fluctuations commonly observed in biological populations, including range and time intervals of these phenomena (Andrewartha \& Birch, 1982). Among the mechanisms controlling population fluctuations, natural (such as seasonal and/or annual cycles) and induced (for example, anthropogenic changes) disturbances are recognized as the most important (Wittings et al., 1999; Agostinho et al., 2007). In both cases, the disturbances promote changes in spatial and temporal heterogeneity of ecosystems, causing extreme changes in the relative abundance of species (Pickett \& White, 1985).

In tropical and subtropical river environments, the seasonal variations in fluviometric levels (natural disturbances) are, for some authors (Welcomme, 1979; Oldani, 1990; Agostinho et

${ }^{1}$ Universidade Federal de Santa Catarina, Laboratório de Biologia e Cultivo de Peixes de Água Doce (LAPAD). Rodovia SC 406, Km3, ${ }^{\circ}$ 3532, Armação, 88066-000 Florianópolis, SC, Brazil. reynalted@hotmail.com

${ }^{2}$ Universidade Estadual de Maringá, Núcleo de Pesquisas em Limnologia, Ictiologia e Aquicultura (Nupélia). Av. Colombo, 5790, bloco G90, 87020-900 Maringá, Paraná, Brazil. 
al., 2004a), the main force influencing the population dynamics of several aquatic communities. The increase in river level homogenizes the limnologic conditions of environments (Thomaz et al., 2007), increases physical space for colonizers and the availability of resources and shelter (Agostinho et al., 2004b), and is responsible for maintaining species diversity (Agostinho \& Zalewski, 1995). However, the interruption of the rivers to construct dams negatively influences these characteristics because it changes the physical and chemical conditions of the water and also influences the abundance and quality of specific habitat types (Agostinho et al., 2007).

As a consequence of dams, these and other changes create pronounced alterations in the fish fauna, mainly in the composition and structure of fish assemblages, causing a variable period of instability (Petrere Jr., 1996; Agostinho et al., 2004b). Several studies have evaluated the changes in the organization of adult fish assemblages (Ponton \& Vauchel, 1998; Agostinho et al., 2004b), but studies that consider the changes in the structure of ichthyoplankton assemblages are scarce (Humphries \& Lake, 2000; Sanches et al., 2006).

Information on the ecology of fish eggs and larvae is extremely important for understanding the biology of species, since the early stages represent a critical period in their life cycle (Fuiman, 2002). Some studies have shown that environmental variables are the main determinants of ichthyoplankton abundance, structure and composition variation (Keckeis et al., 2000; Reynalte-Tataje et al., 2012). However, the effect of dams on the ichthyoplankton community is rarely investigated (Humphries \& Lake, 2000; Sanches et al., 2006).

Studies evaluating the temporal variation of fish larvae assemblages for several reproductive periods are nonexistent for the upper Uruguay River region and rare for the Prata River basin as a whole. Such studies would be extremely useful for understanding the relationship of the ichthyoplankton community to different environments and for evaluating dam impacts on that community. This study evaluates the temporal variability of larval assemblages in the upper Uruguay River mouth environments. Specifically, the objectives are: (i) to characterize the taxonomic composition and ichthyoplankton larval development; (ii) to assess and compare the temporal variability of assemblages and (iii) to determine the influence of environmental variables in the main taxa in a controlled river mouth environment and a free river mouth environment. Our hypotheses are: a) seasonal sequence in the occurrence of species or in the structure of larvae assemblages varies drastically among years and this pattern is associated with inter-annual variation in larval supply; b) sampling sites influenced by dams suffer different variation on larval assemblage structure than those sites situated in the stretches of the river free of dams.

\section{Material and Methods}

\section{Study area}

The upper Uruguay River region is situated in an enclosed valley, characterized by a steep incline and a flood regime determined largely by rain in the riverbed. The main river is characterized by areas of still water separated by rapids, waterfalls and gorges, while the tributaries, which are not very long, have many waterfalls, making the movement of rheophilic species from the main river and back more difficult (Zaniboni-Filho \& Schulz, 2003). Despite the lack of floodplain areas (known as nurseries), previous regional studies have shown that during the rainy season, areas near the tributaries mouths are dammed by the Uruguay River and form backwaters, which are ideal places for the initial stages of fish development (Zaniboni-Filho \& Schulz, 2003; Hermes-Silva et al., 2009).

Because it shows a steep incline, the upper Uruguay River region has been a focus of interest from entities involved in hydroelectric development, and six dams have been set up, two of which are situated at the Uruguay River itself: the Itá HPP (Hydroelectric Power Plant), which began operations in 2000 , is situated approximately $230 \mathrm{~km}$ from the confluence of Canoas and Pelotas Rivers (Uruguay River beginning); and the Machadinho HPP, which was dammed in 2001, and is 135 $\mathrm{km}$ upstream from Itá. This study was conducted at the mouth of the two tributaries of the Uruguay River (Ligeiro and Chapecó) located between the states of Santa Catarina and Rio Grande do Sul in Brazil (Fig. 1). The selected sections were the following:

a. Ligeiro ( $\left.27^{\circ} 31^{\prime} \mathrm{S} 51^{\circ} 50^{\prime} \mathrm{W}\right)$ located $5 \mathrm{~km}$ downstream from Machadinho HPP and approximately $130 \mathrm{~km}$ upstream from the Itá dam. This tributary flows into the Uruguay River in the only lotic stretch (approximately $6 \mathrm{~km}$ ) between those two dams. This section encompasses the Uruguay-Ligeiro (ULIG) sampling site on the Uruguay River (main river) and the Ligeiro (LIG) sampling site on the Ligeiro River. The Itá and Machadinho HPPs directly influence the fish fauna of this section.

b. Chapecó $\left(27^{\circ} 05^{\prime} \mathrm{S} 53^{\circ} 01^{\prime} \mathrm{W}\right)$, located downstream from Itá HPP, is approximately $110 \mathrm{~km}$ from the dam. The Chapecó River is a main tributary of the upper portion of the Uruguay River basin. In this section, the Uruguay-Chapecó (UCH) sampling site on the Uruguay River (main river) and the Chapecó $(\mathrm{CH})$ sampling site on the Chapecó River were selected. Due to the distance from the Itá HPP and based on monitoring studies conducted in the region (Zaniboni-Filho et al., 2008), it is believed that the dams upstream do not impact the environment.

\section{Sampling}

The sampling procedures to obtain the eggs and larvae were conducted during three consecutive reproductive periods (RP): October 2001 to March 2002 (RP1), October 2002 to March 2003 (RP2) and October 2003 to March 2004 (RP3). Within each sampling site, the collections were conducted at 2 points for 2 days in 6-hour intervals (0300h, 0900h, 1500h and 2100h). The abundance of each site was represented by the sum of the abundance of the 


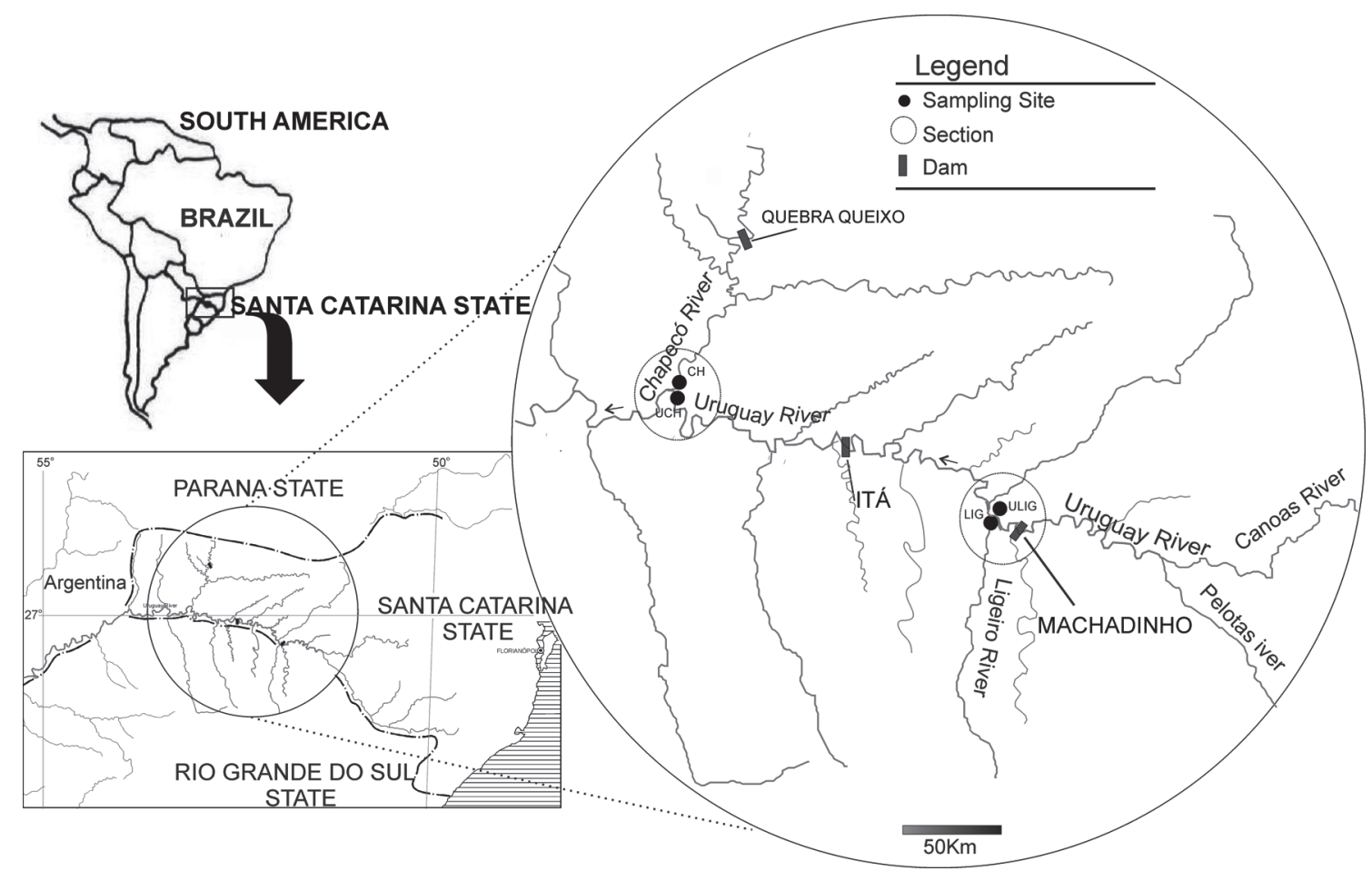

Fig. 1. Location of the sampling sites in the upper Uruguay River in southern Brazil. Samplings sites: LIG: Ligeiro, ULIG: Uruguay-Ligeiro, CH: Chapecó, UCH: Uruguay-Chapecó.

4 collections, which summed up 4 estimates of larvae abundance each month for each sampling site ( 2 points $\mathrm{x}$ 2 days). For this study, $0.5 \mathrm{~mm}$ mesh cylindroconical plankton nets with a mouth area of $0.109 \mathrm{~m}^{2}$ were used, and a flow meter was attached to each net to record the volume of filtered water. The nets remained in the water, at the same time of day for 1 hour, at all the sampling sites and were tied to a cable stretched from one bank of the river to the other at each sampling site (Hermes-Silva et al., 2009). In situations where the tributary river was dammed by the main river (stream speed $<0.01 \mathrm{~m} \cdot \mathrm{s}^{-1}$ ), surface trawls were done for 20 minutes by a boat at low speed. All the material collected was fixed in $4 \%$ formalin buffered with $\mathrm{CaCO}_{3}$.

At each sampling site, water temperature $\left({ }^{\circ} \mathrm{C}\right)$, dissolved oxygen $\left(\mathrm{mg} . \mathrm{L}^{-1}\right), \mathrm{pH}$ and water transparency $(\mathrm{cm})$ were measured. Water precipitation and stream flow data were obtained through records supplied by ANEEL (National Electric Energy Agency) and by the Itá and Machadinho HPP control' house.

The samples content were checked in laboratory, and the larvae were separated from the rest of the plankton. Based on Tanaka (1973), the abundance of larvae was standardized for a $10 \mathrm{~m}^{3}$ volume. The larvae were removed from the collected material and classified into the lowest possible taxonomic level, according to Nakatani et al. (2001) and Reynalte-Tataje \& Zaniboni-Filho (2008).

\section{Data analysis}

The separated larvae were classified, in stages, according to their degree of development: larval yolk (LY), pre-flexion (PF), flexion (FL) and post-flexion (FP), according to Ahlstrom $\&$ Moser (1976) and modified by Nakatani et al. (2001). The stations with larvae in the final stages of development (FL and FP) were considered growing and feeding areas for larvae (nurseries) and drifting areas for those stations where the larvae were mainly in the initial stages (LY and PF).

To evaluate the space-time variation (factors: sampling sites, reproductive period and months) of the most abundant species in the assemblages (frequency of occurrence [F.O]. > 5.0\%), a nested analysis of variance (nested ANOVA) was applied (Hicks, 1993). To reduce the variability of abundance data and achieve the assumptions of ANOVA the densities were logtransformed $\left(\log _{10} x+1\right)$. The variation fraction explained by the spatial and temporal scales (monthly and annual) for each species and compared to the model $\left(\mathrm{R}^{2}\right)$ was also calculated (Hicks 1993; Witting et al., 1999). These calculations were done in the SYSTAT v10 software (Wilkinson, 1998).

To test the temporal persistence in the structure of fish larvae assemblages from different sampling sites, Spearman correlations among the abundance of different reproductive periods were used, and the abundances of species were ranked for each reproductive period (Sokal \& Rohlf, 1981).

To evaluate the influence of environmental variables in the abundance of larvae, Pearson correlations were 
performed. Previously, to reduce the dimensionality of environmental variables, a Principal Components Analysis (PCA) was applied. All the variables, with the exception of $\mathrm{pH}$, were transformed $\left(\log _{10} \mathrm{x}\right)$ to linearize the intervariable correlations (Peters, 1986). Environmental variables that showed higher than 0.4 structural coefficients were considered biologically important (Hair et al., 1984). Only the axes, which showed auto-values higher than those randomly generated, were retained for interpretation (Broken-Stick criteria; Jackson, 1993).

\section{Results}

\section{Taxonomic composition and larval development of the ichthyoplankton}

During the study period, 264 samples were collected, among which 118,415 eggs and 6,321 larvae were found (5.3\% of the ichthyoplankton collected). These larvae belonged to five orders, 20 families, 39 genera and 41 species. Out of the total number of larvae caught, the Characiformes contributed $45.5 \%$, the Siluriformes $40.1 \%$ and the Gymnotiformes $6.3 \%$. The Perciformes and Atheriniformes orders and the larvae that were not identified represented approximately $8 \%$ of the captured larvae. In general, the larval assemblages were composed mostly of small and medium-sized Characiformes and Siluriformes, and they show short migrations. Larvae of species that make long reproductive migrations, such as the Prochilodus lineatus and Leporinus obtusidens, were not very frequent ( $1.9 \%$ and $0.8 \%$ respectively), and they were restricted to the Chapecó section. Larvae of $P$. lineatus were observed between November and January in RP1 and RP2, whereas the L. obtusidens larvae were recorded only in RP1. Table 1 shows the most frequent taxa (F.O. $>5 \%$ ) during the period of study.

Larval development analysis showed clear differences in the composition of initial stages during reproductive periods. RP1 and RP3 showed similar abundances for initial stages (LY and PF). However, RP1 showed a higher flexion and post-flexion larvae density. In RP2, the densities for all the stages were lower, and there was a steady reduction of larvae density in late stages, and no individual was observed in post-flexion during this studied period in any of the sampling sites (Fig. 2).

\section{Space-time variation of main taxa}

During the study, approximately $85 \%$ of the variation in the distribution of larvae during the reproductive period was temporal $(53.0 \%$ monthly and $33.9 \%$ from the reproductive period), and the spatial influenced only $13.1 \%$. Parapimelodus valenciennis was the species with higher spatial variation at $35.1 \%$. Oligosarcus jenynsii and Acestrorhynchus pantaneiro showed the highest variation between the years, and Leporinus amae with $66.7 \%$, had the highest monthly variation (Table 2 ).

\section{Temporal variability of larvae assemblages}

Differences in the temporal variability of the assemblage structures were observed among the sampling sites. The larvae assemblage from the LIG section showed that RP2 was

Table 1. Composition, average density (larvae. $10 \mathrm{~m}^{-3}$ ), frequency of occurrence (F.O. \%) and the occurrence of fish larvae collected in different months and sampling sites in the upper Uruguay River from October 2001 to March 2004. * $1=\mathrm{RP} 1 ; 2=$ $\mathrm{RP} 2$ and 3=RP3. ${ }^{* *} \mathrm{X}=$ Indicates the presence in the sampling sites: LIG: Ligeiro, ULIG: Uruguay-Ligeiro, CH: Chapecó, UCH: Uruguay-Chapecó. ${ }^{1} \mathrm{~S}=$ Sedentary, $\mathrm{SM}=$ Short migration. $\mathrm{U}=$ Unknown reproductive strategy.

\begin{tabular}{|c|c|c|c|c|c|c|c|c|c|c|c|c|c|}
\hline \multirow{2}{*}{ Taxa } & \multirow{2}{*}{$\begin{array}{c}{ }^{1} \text { Reproductive } \\
\text { Strategy }\end{array}$} & \multirow{2}{*}{ Dens. } & \multirow{2}{*}{ F.O.\% } & \multicolumn{6}{|c|}{ Month* } & \multicolumn{4}{|c|}{ Sampling Sites** } \\
\hline & & & & Oct & Nov & Dec & Jan & Feb & Mar & LIG & ULIG & $\mathrm{CH}$ & $\mathrm{UCH}$ \\
\hline Acestrorhynchus pantaneiro & $\bar{U}$ & 8.8 & 6.18 & 3 & 1,3 & 1 & 3 & & & $\mathrm{x}$ & $\mathrm{x}$ & $\mathrm{x}$ & $\mathrm{x}$ \\
\hline Apareiodon affinis & SM & 8.9 & 7.08 & & 1,3 & 1 & $1,2,3$ & 1 & & $\mathrm{x}$ & & $\mathrm{x}$ & $\mathrm{x}$ \\
\hline Astyanax jacuhiensis & $\mathrm{S}$ & 65.5 & 8.39 & $1,2,3$ & $1,2,3$ & $1,2,3$ & 1,3 & 2 & 3 & $\mathrm{x}$ & $\mathrm{x}$ & $\mathrm{x}$ & $\mathrm{x}$ \\
\hline Astyanax fasciatus & SM & 29.2 & 25.29 & 1,3 & $1,2,3$ & $1,2,3$ & 1,3 & 2 & 3 & $\mathrm{x}$ & $\mathrm{x}$ & $\mathrm{x}$ & $\mathrm{x}$ \\
\hline Astyanax gr. scabripinnis & SM & 14.8 & 20.58 & 3 & $1,2,3$ & 1,2 & $1,2,3$ & 1,3 & 2,3 & $\mathrm{x}$ & $\mathrm{x}$ & $\mathrm{x}$ & $\mathrm{x}$ \\
\hline Bryconamericus iheringii & SM & 22.5 & 13.17 & 1,3 & $1,2,3$ & 1,3 & $1,2,3$ & 1,3 & $1,2,3$ & $\mathrm{x}$ & $\mathrm{x}$ & $\mathrm{x}$ & $\mathrm{x}$ \\
\hline Bryconamericus stramineus & SM & 30.8 & 16.29 & 3 & 1,3 & 1,3 & $1,2,3$ & 1,3 & 2,3 & $\mathrm{x}$ & $\mathrm{x}$ & $\mathrm{x}$ & $\mathrm{x}$ \\
\hline Eigenmannia virescens & $\mathrm{S}$ & 8.1 & 17.26 & & 1,3 & $1,2,3$ & $1,2,3$ & $1,2,3$ & 3 & $\mathrm{x}$ & $\mathrm{x}$ & $\mathrm{x}$ & $\mathrm{x}$ \\
\hline Gymnotus carapo & $\mathrm{S}$ & 3.6 & 6.94 & & 1,2 & 1 & $1,2,3$ & 1,2 & & $\mathrm{x}$ & $\mathrm{x}$ & $\mathrm{x}$ & $\mathrm{x}$ \\
\hline Hoplias spp. & $\mathrm{S}$ & 3.7 & 8.95 & & 1,3 & $1,2,3$ & $1,2,3$ & $1,2,3$ & 1,3 & $\mathrm{x}$ & $\mathrm{x}$ & $\mathrm{x}$ & $\mathrm{x}$ \\
\hline Hypostomus spp. & $\mathrm{S}$ & 15.1 & 7.56 & 1 & $1,2,3$ & 1,3 & $1,2,3$ & 1,2 & 2,1 & $\mathrm{x}$ & $\mathrm{x}$ & $\mathrm{x}$ & $\mathrm{x}$ \\
\hline Leporinus amae & SM & 5.2 & 9.02 & & $1,2,3$ & 1,3 & $1,2,3$ & 3 & & $\mathrm{x}$ & $\mathrm{x}$ & $\mathrm{x}$ & $\mathrm{x}$ \\
\hline Oligosarcus jenynsii & $\mathrm{U}$ & 1.1 & 7.63 & & 1,3 & 3 & $1,2,3$ & 1,3 & 3 & $\mathrm{x}$ & $\mathrm{x}$ & $\mathrm{x}$ & $\mathrm{x}$ \\
\hline Parapimelodus valenciennis & SM & 52.7 & 13.93 & 1,3 & 1,3 & $1,2,3$ & $1,2,3$ & 1,3 & 1,3 & $\mathrm{x}$ & $\mathrm{x}$ & $\mathrm{x}$ & $\mathrm{x}$ \\
\hline Pimelodella $\mathrm{sp}$ & SM & 1.2 & 6.52 & & 1,3 & 1 & 1,3 & 1 & 1 & $\mathrm{x}$ & $\mathrm{x}$ & $\mathrm{x}$ & $\mathrm{x}$ \\
\hline Pimelodus absconditus & SM & 29.4 & 6.18 & & 1,3 & 1,2 & 1 & & & $\mathrm{x}$ & & $\mathrm{x}$ & $\mathrm{x}$ \\
\hline Pimelodus atrobrunneus & SM & 27.7 & 8.53 & & $1,2,3$ & 1,2 & 3 & 1 & 3 & $\mathrm{x}$ & $\mathrm{x}$ & $\mathrm{x}$ & $\mathrm{x}$ \\
\hline Pimelodus maculatus & SM & 4.4 & 32.77 & 3 & $1,2,3$ & $1,2,3$ & 2,3 & $1,2,3$ & 3 & $\mathrm{x}$ & $\mathrm{x}$ & $\mathrm{x}$ & $\mathrm{x}$ \\
\hline Rhamdia quelen & SM & 1.7 & 33.81 & 1,3 & $1,2,3$ & 1,3 & $1,2,3$ & 1,3 & 2,3 & $\mathrm{x}$ & $\mathrm{x}$ & $\mathrm{x}$ & $\mathrm{x}$ \\
\hline Schizodon nasutus & SM & 10.1 & 16.43 & 3 & $1,2,3$ & 1,3 & $1,2,3$ & 3 & 3 & $\mathrm{x}$ & $\mathrm{x}$ & $\mathrm{x}$ & $\mathrm{x}$ \\
\hline Steindachnerina spp. & SM & 12.1 & 6.94 & & $1,2,3$ & 1 & & 3 & & $\mathrm{x}$ & $\mathrm{x}$ & $\mathrm{x}$ & $\mathrm{x}$ \\
\hline
\end{tabular}



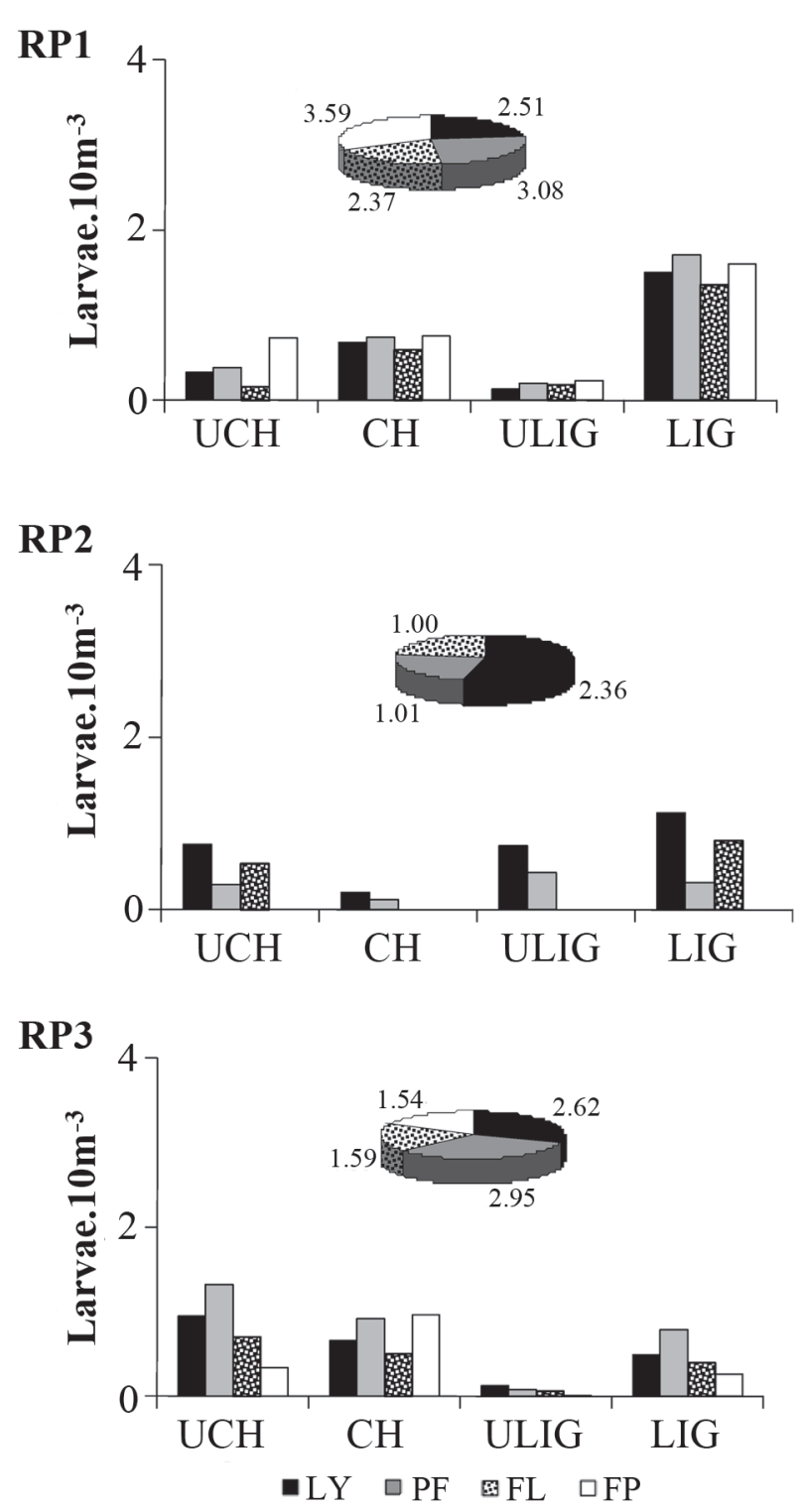

Fig. 2. Abundance of fish larvae in different stages of development recorded in the sampling sites of the upper Uruguay River from October 2001 to March 2004. Larval development stages: $\mathrm{LY}=$ Larval Yolk; $\mathrm{PF}=$ Pre-flexion; $\mathrm{FL}=$ Flexion and FP = Post-flexion. Sampling sites: LIG: Ligeiro, ULIG: Uruguay-Ligeiro, CH: Chapecó and UCH: UruguayChapecó. Reproductive Periods: RP1: First Reproductive Period, RP2: Second Reproductive Period and RP3: Third Reproductive Period.

consistent with RP1 ( $\mathrm{r}=0.40 ; \mathrm{p}<0.05)$, whereas RP3 showed a different composition from that found in RP1 $(\mathrm{r}=0.24 ; \mathrm{p}>0.05)$ and RP2 ( $\mathrm{r}=0.00 ; \mathrm{p}>0.05$ ) (Table 3 ).

Larval assemblages showed similarities between RP1 and RP3 at ULIG $(r=0.40 ; p<0.05)$ and $\mathrm{CH}$ sites $(r=0.57 ; \mathrm{p}<0.05)$. However, the RP2 assemblage was different in both sites (Table 3). The larval assemblage structure at the UCH site showed differences between RP2 and RP3.

In general, the larval assemblage structure at the Ligeiro ( $\mathrm{LIG}=0.38$; ULIG $=0.30$ ) section showed a higher temporal variability than the larval assemblage of the Chapecó section $(\mathrm{CH}=0.48 ; \mathrm{UCH}=0.51)$ (Table 3$)$.

\section{Environmental variables and their influence on the main taxa}

When combined, the two axes selected by the brokenstick criteria explained $59.5 \%$ of the data variability. The first axis (PC1) showed an auto-value of 2.31 and explained $39.4 \%$ of the variability. The environmental variable that contributed most negatively to its formation was the stream flow $(\mathrm{r}=-0.62 ; \mathrm{p}<0.01)$, and the variables that contributed most positively were temperature $(\mathrm{r}=0.57 ; \mathrm{p}<0.01)$ and water transparency $(\mathrm{r}=0.49 ; \mathrm{p}<0.05)$. In the second axis ( $\mathrm{PC} 2$, with an auto-value of 1.44), $\mathrm{pH}$ contributed negatively ( $\mathrm{r}=$ $-0.58 ; \mathrm{p}<0.01)$ and dissolved oxygen contributed positively $(\mathrm{r}=0.51 ; \mathrm{p}<0.01)$, which explained $20.1 \%$ of the variability (Fig. 3).

The PCA showed differences among the three reproductive periods. RP2 showed higher stream flow values when compared to RP1 and RP3, which showed lower water flow values and higher water temperature and transparency, with the exception of the month of October at RP1, which showed inverse values. In general, this period showed higher water disturbances than the other two (Fig. 3).

The highest egg densities were recorded when low water flow values were predominant $(\mathrm{r}=-0.473 ; \mathrm{P}<0.05)$, whereas the larvae density showed a positive correlation with temperature $(\mathrm{r}=0.563 ; \mathrm{P}<0.05)$ and an inverse correlation with water flow $(\mathrm{r}=-0.331 ; \mathrm{P}<0.05)$. The most abundant taxa density correlation with environmental variables is shown on Table 4.

\section{Discussion}

Larval assemblages were mainly composed of small and medium-sized Characiformes and Siluriformes. From the 41 species identified, 32 are opportunists, i.e., species that show alternate spawning, long reproductive periods, small eggs, lack of parental care and small reproductive migrations (Suzuki et al., 2005). The larvae of large migratory Characiformes (Leporinus obtusidens and Prochilodus lineatus) were recorded only in the Chapecó section despite the fact that adult individual fish have been recorded in all the studied environments (Zaniboni-Filho et al., 2008). In the three studied years, the absence of those migratory species upstream from the Itá dam indicates that they present low reproductive activity in the stretch between the Machadinho and Itá HPPs or those species are unable to reproduce.

In the four sampling sites, larvae in all stages were recorded, but we observed differences among the three reproductive periods. The greater abundance of larvae in advanced stages (flexion and post-flexion) in RP1 and RP3 seems to indicate the prevalence of environmental conditions, such as the presence of backwater areas and areas of food availability. The low abundance of larvae in flexion and the 
Table 2. ANOVA nested results in the most abundant taxa density variation in studied environments in the three reproductive periods, between October 2001 and March 2004. Numbers in bold represent $\mathrm{p}<0.05$.

\begin{tabular}{lccccccc}
\hline \multirow{2}{*}{ Taxa } & \multirow{2}{*}{$\mathrm{R}^{2}$} & \multicolumn{3}{c}{ Site } & \multicolumn{2}{c}{$\mathrm{RP}$ (Site) } & \multicolumn{2}{c}{ Month (Site*RP) } \\
\cline { 3 - 8 } & & $\%$ & $\mathrm{~F}$ & $\%$ & $\mathrm{~F}$ & $\%$ & $\mathrm{~F}$ \\
\hline Acestrorhynchus pantaneiro & $\mathbf{0 . 4 5}$ & 7.2 & 0.99 & 56.7 & $\mathbf{2 . 8 0}$ & 36.1 & $\mathbf{2 . 0 0}$ \\
Apareiodon affinis & 0.25 & 6.9 & 0.79 & 34.8 & 0.99 & 58.3 & 1.01 \\
Astyanax jacuhiensis & 0.26 & 23.2 & $\mathbf{2 . 7 2}$ & 16.1 & 0.46 & 60.8 & 1.08 \\
Astyanax fasciatus & $\mathbf{0 . 4 4}$ & 17.8 & $\mathbf{5 . 2 3}$ & 31.7 & $\mathbf{2 . 3 5}$ & 50.5 & $\mathbf{2 . 2 7}$ \\
Astyanax gr. scabripinnis & $\mathbf{0 . 4 0}$ & 10.6 & 2.36 & 28.9 & 1.61 & 60.4 & $\mathbf{2 . 0 8}$ \\
Bryconamericus iheringii & $\mathbf{0 . 3 1}$ & 17.0 & $\mathbf{3 . 0 2}$ & 36.4 & 1.62 & 46.7 & 1.27 \\
Bryconamericus stramineus & $\mathbf{0 . 3 2}$ & 18.8 & $\mathbf{3 . 5 3}$ & 33.9 & 1.59 & 47.3 & 1.31 \\
Eigenmannia virescens & $\mathbf{0 . 4 3}$ & 8.8 & $\mathbf{3 . 0 0}$ & 50.9 & $\mathbf{4 . 2 8}$ & 40.3 & $\mathbf{2 . 0 6}$ \\
Gymnotus carapo & 0.28 & 15.6 & 1.98 & 30.8 & 0.97 & 53.6 & 1.21 \\
Hoplias spp. & 0.29 & 5.8 & 0.78 & 31.5 & 1.05 & 62.7 & 1.28 \\
Hypostomus spp. & 0.25 & 5.8 & 0.63 & 31.5 & 0.69 & 62.7 & 1.05 \\
Leporinus amae & 0.27 & 2.5 & 0.29 & 30.8 & 0.91 & 66.7 & 1.21 \\
Oligosarcus jenynsii & $\mathbf{0 . 3 7}$ & 9.0 & $\mathbf{2 . 4 9}$ & 57.0 & $\mathbf{3 . 1 9}$ & 34.0 & $\mathbf{1 . 6 8}$ \\
Parapimelodus valenciennis & $\mathbf{0 . 5 4}$ & 35.1 & $\mathbf{3 . 3 6}$ & 35.0 & $\mathbf{3 . 4 2}$ & 29.9 & $\mathbf{3 . 1 6}$ \\
Pimelodella sp. & 0.25 & 7.0 & 0.80 & 44.5 & 1.23 & 48.5 & 0.97 \\
Pimelodus absconditus & 0.26 & 25.1 & $\mathbf{2 . 7 4}$ & 23.2 & 0.63 & 51.7 & 1.03 \\
Pimelodus atrobrunneus & $\mathbf{0 . 4 3}$ & 7.7 & 1.95 & 31.9 & $\mathbf{2 . 0 1}$ & 60.4 & $\mathbf{2 . 3 3}$ \\
Pimelodus maculatus & $\mathbf{0 . 5 5}$ & 11.7 & $\mathbf{4 . 7 7}$ & 26.8 & $\mathbf{2 . 7 5}$ & 61.5 & $\mathbf{3 . 8 4}$ \\
Rhamdia quelen & $\mathbf{0 . 5 2}$ & 10.5 & $\mathbf{3 . 8 0}$ & 28.7 & $\mathbf{2 . 6 0}$ & 60.8 & $\mathbf{3 . 3 6}$ \\
Schizodon nasutus & $\mathbf{0 . 4 4}$ & 13.1 & $\mathbf{3 . 4 2}$ & 26.2 & 1.70 & 60.6 & $\mathbf{2 . 4 1}$ \\
Steindachnerina spp. & $\mathbf{0 . 3 9}$ & 16.7 & $\mathbf{3 . 0 3}$ & 24.3 & 1.10 & 59.0 & $\mathbf{1 . 9 6}$ \\
\hline
\end{tabular}

absence of post-flexion in the RP2 in all the study area could be a result of the hydrodynamics presented during that period (a high water flow and speed and low transparency and water temperature) not allowing the establishment of larvae and/or their food (other planktonic and benthic preys).

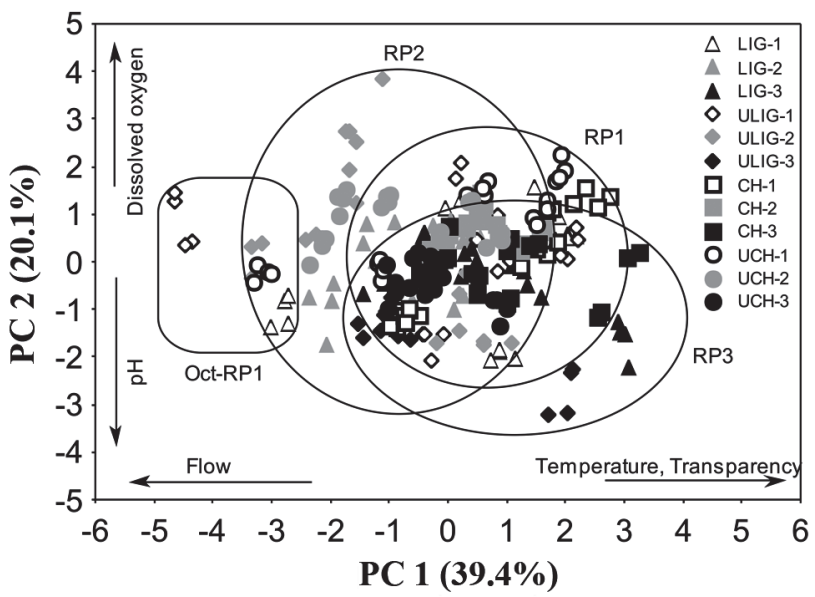

Fig. 3. Principal Components Analysis of the environmental variables' matrixes recorded in the upper Uruguay River between October 2001 and March 2004. Sampling sites: LIG: Ligeiro, ULIG: Uruguay-Ligeiro, $\mathrm{CH}$ : Chapecó and UCH: Uruguay-Chapecó. Reproductive Periods: RP1: First Reproductive Period, RP2: Second Reproductive Period and RP3: Third Reproductive Period.
During the studied period, we observed a greater variation in the temporal scale than in the spatial scale among the main taxa presented in the ichthyoplanktonic assemblage, suggesting a high degree of temporal, mainly seasonal, unpredictability. The highest temporal variation could be explained by four factors: first, the fact that the largest part of these species showed pronounced peaks in a few months and, subsequently, showed a decrease or absence in the following months, which would explain the high monthly variation; second, the influence of several environmental variations among the three reproductive periods; third, the fact that the most abundant species were present in most of the studied sites, reducing the spatial variation; and, fourth, mainly in the case of the Ligeiro section, the influence of the dams on the establishment of the community after the filling of these reservoirs.

The correlation analysis among the reproductive periods indicated that the assemblage composition changed substantially over time in the LIG, ULIG and CH sites. For these environments, the correlation values usually remained below 0.5 , indicating a low similarity in the total composition and abundance of larvae among years. When comparing the three reproductive periods (with exception of the LIG site), we noticed that there is a major similarity in the structure of larval assemblage between RP1 and RP3. These periods showed higher temperature and water transparency than RP2, which, in turn, showed a higher average water flow when compared to the others, indirectly reducing water temperature and transparency values. 
Table 3. Abundance ranking for each reproductive period, by sampling site and average \pm standard error (SE) of larvae density from the 21 most frequent species. Correlation matrix between reproductive periods among most abundant species. Numbers in bold represent $\mathrm{p}<0.05$.

\begin{tabular}{|c|c|c|c|c|c|c|c|c|c|c|c|c|}
\hline \multirow{2}{*}{ Taxa } & \multicolumn{3}{|c|}{ LIG } & \multicolumn{3}{|c|}{ ULIG } & \multicolumn{3}{|c|}{$\mathrm{CH}$} & \multicolumn{3}{|c|}{$\mathrm{UCH}$} \\
\hline & RP1 & RP2 & RP3 & RP1 & RP2 & RP3 & RP1 & RP2 & RP3 & RP1 & RP2 & RP3 \\
\hline Acestrorhynchus pantaneiro & 21 & 21 & 6 & 21 & 21 & 16 & 17 & 21 & 21 & 16 & 21 & 14 \\
\hline Apareiodon affinis & 16 & 21 & 2 & 21 & 21 & 21 & 12 & 21 & 21 & 12 & 9 & 15 \\
\hline Astyanax jacuhiensis & 13 & 21 & 21 & 4 & 10 & 21 & 9 & 21 & 21 & 5 & 3 & 13 \\
\hline Astyanax fasciatus & 6 & 3 & 11 & 6 & 3 & 1 & 1 & 1 & 2 & 1 & 2 & 1 \\
\hline Astyanax gr. scabripinnis & 2 & 1 & 21 & 3 & 21 & 5 & 13 & 21 & 4 & 8 & 4 & 3 \\
\hline Bryconamericus iheringii & 5 & 21 & 12 & 5 & 1 & 6 & 7 & 21 & 5 & 6 & 8 & 4 \\
\hline Bryconamericus stramineus & 15 & 21 & 21 & 21 & 21 & 21 & 21 & 21 & 21 & 21 & 21 & 21 \\
\hline Eigenmannia virescens & 7 & 21 & 7 & 2 & 7 & 13 & 3 & 3 & 21 & 13 & 10 & 5 \\
\hline Gymnotus carapo & 18 & 21 & 10 & 8 & 9 & 21 & 18 & 21 & 21 & 19 & 13 & 21 \\
\hline Hoplias spp. & 14 & 7 & 8 & 14 & 6 & 15 & 6 & 5 & 8 & 3 & 15 & 7 \\
\hline Hypostomus spp. & 8 & 21 & 9 & 10 & 4 & 9 & 15 & 4 & 21 & 18 & 14 & 12 \\
\hline Leporinus amae & 10 & 5 & 21 & 21 & 2 & 8 & 11 & 21 & 7 & 10 & 21 & 9 \\
\hline Oligosarcus jenynsii & 17 & 21 & 21 & 7 & 21 & 2 & 14 & 6 & 6 & 20 & 11 & 10 \\
\hline Parapimelodus valenciennis & 3 & 6 & 21 & 9 & 21 & 3 & 8 & 21 & 21 & 15 & 5 & 18 \\
\hline Pimelodella $\mathrm{sp.}$ & 9 & 21 & 21 & 12 & 21 & 12 & 16 & 21 & 21 & 17 & 21 & 17 \\
\hline Pimelodus absconditus & 19 & 21 & 21 & 21 & 21 & 21 & 21 & 21 & 21 & 14 & 7 & 19 \\
\hline Pimelodus atrobrunneus & 12 & 21 & 1 & 21 & 21 & 7 & 10 & 21 & 10 & 4 & 6 & 11 \\
\hline Pimelodus maculatus & 11 & 21 & 4 & 21 & 5 & 14 & 2 & 2 & 1 & 2 & 1 & 2 \\
\hline Rhamdia quelen & 1 & 4 & 5 & 1 & 7 & 4 & 5 & 21 & 9 & 9 & 21 & 6 \\
\hline Schizodon nasutus & 4 & 2 & 3 & 13 & 21 & 11 & 4 & 21 & 3 & 11 & 16 & 8 \\
\hline \multirow[t]{2}{*}{ Steindachnerina spp. } & 21 & 21 & 21 & 11 & 21 & 10 & 21 & 21 & 21 & 7 & 12 & 16 \\
\hline & & LIG & & & ULIG & & & $\mathrm{CH}$ & & & $\mathrm{UCH}$ & \\
\hline RP1*RP2 & & 0.65 & & & 0.30 & & & 0.47 & & & 0.52 & \\
\hline $\mathrm{RP} 1 * \mathrm{RP} 3$ & & 0.11 & & & 0.45 & & & 0.62 & & & 0.67 & \\
\hline $\mathrm{RP} 2 * \mathrm{RP} 3$ & & 0.00 & & & 0.16 & & & 0.34 & & & 0.33 & \\
\hline Correlation average (site) & & 0.38 & & & 0.30 & & & 0.48 & & & 0.51 & \\
\hline
\end{tabular}

The reduction in larval abundance, the lower number of taxa, the absence of individuals in post-flexion stage and the high dissimilarity in larval assemblage structure found in RP2, seem to indicate that the environmental conditions in that period acted negatively on the reproductive activity of most fish species of the region. Similar results were also found for other sampling sites in the upper Uruguay River region for the same period (Reynalte-Tataje et al., 2008).

Most of the prior studies conducted in the Plata River basin consider that the majority of the reproductive activity happens at the peak of the hydrometric level (Bayley, 1973; Agostinho et al., 2004b). However, some studies in the Plata, lower Uruguay and lower Paraná rivers show that variations in hydrometric level are not particularly important and that temperature is the main stimulus for reproduction (Oldani, 1990). Based on our current findings (a higher reproductive success in RP1 and RP3), there are evidences showing the influence of flow and water temperature on the reproductive activity of fish in the upper Uruguay River region, suggesting a hypothesis that water temperature, more than flow, could act as a critical factor influencing the reproduction of the majority fish species at this latitude.

Water temperature may also influence reproduction and, consequently, monthly distribution of ichthyoplankton organisms. During the study, larvae were found between October and March for all the reproductive periods. Nevertheless, some differences were observed. In October of
$\mathrm{RP} 2$, the presence of only one taxon (A. jacuhiensis) was recorded, which contrasted with RP1 and RP3, where 11 taxa were recorded. It is believed that the low temperatures in October of RP2 may have delayed the reproductive activity of species and that the low temperature values in the spring may have negatively influenced reproduction during this reproductive period.

In contrast to RP2, RP1 showed the highest values of abundance and number of taxa and a higher presence of larvae in the final stages of development. In this period, the presence of larvae from migratory species $L$. obtusidens and P. lineatus was also recorded in the Chapecó section. This period was characterized by substantial disturbances in hydrological behavior, occurring floods during October and a very pronounced drought in the following months. This variation in hydrodynamics seems to have favored the reproductive success of the fish assemblage.

The importance of hydrological disturbance in lotic environments has been broadly recognized because it produces a larger number of indicators and induces the reproduction of species with different reproductive strategies (Nesler et al., 1988; Poff \& Allan, 1995).

Hence, some species, such as Parapimelodus valenciennis and Astyanax fasciatus, are favored by the increase in water flow, whereas others, such as Bryconamericus stramineus and Rhamdia quelen, are more abundant in dry periods. In this sense, global hydrological 
Table 4. Pearson correlation among the environmental variables and eggs, larvae and the most abundant taxa $\left(\operatorname{density} \log _{10} \mathrm{x}\right.$ +1 ) in the upper Uruguay River from October 2001 to March 2004. Numbers in bold represent $p<0.05$.

\begin{tabular}{|c|c|c|c|c|c|}
\hline Taxa & Flow $\left(\mathrm{m}^{3} \cdot \mathrm{s}^{-1}\right)$ & Temperature $\left({ }^{\circ} \mathrm{C}\right)$ & Transparency $(\mathrm{cm})$ & Dissolved Oxygen (mg.L $\left.\mathrm{L}^{-1}\right)$ & $\mathrm{pH}$ \\
\hline Eggs & -0.473 & 0.042 & 0.043 & -0.064 & -0.102 \\
\hline Larvae & -0.331 & 0.563 & 0.181 & -0.112 & 0.023 \\
\hline Acestrorhynchus pantaneiro & 0.070 & 0.016 & 0.055 & -0.042 & -0.160 \\
\hline Apareiodon affinis & -0.072 & 0.038 & -0.035 & 0.091 & 0.082 \\
\hline Astyanax jacuhiensis & 0.230 & -0.054 & 0.043 & 0.090 & -0.111 \\
\hline Astyanax fasciatus & 0.244 & 0.338 & 0.048 & -0.000 & 0.064 \\
\hline Astyanax gr. scabripinnis & 0.055 & -0.001 & 0.106 & -0.041 & -0.000 \\
\hline Bryconamericus iheringii & 0.100 & 0.243 & 0.243 & -0.064 & -0.141 \\
\hline Bryconamericus stramineus & -0.218 & 0.354 & -0.003 & -0.092 & 0.011 \\
\hline Eigenmannia virescens & 0.015 & 0.353 & 0.067 & -0.123 & 0.083 \\
\hline Gymnotus carapo & -0.065 & 0.311 & 0.200 & 0.000 & 0.191 \\
\hline Hoplias spp. & 0.043 & 0.439 & 0.072 & -0.141 & -0.000 \\
\hline Hypostomus spp. & 0.007 & 0.049 & 0.079 & -0.104 & -0.094 \\
\hline Leporinus amae & 0.018 & -0.001 & -0.054 & -0.051 & -0.050 \\
\hline Oligosarcus jenynsii & 0.009 & 0.385 & 0.284 & -0.162 & -0.094 \\
\hline Parapimelodus valenciennis & 0.245 & -0.050 & 0.039 & -0.091 & -0.332 \\
\hline Pimelodella sp. & 0.024 & 0.007 & 0.098 & 0.070 & 0.102 \\
\hline Pimelodus absconditus & 0.072 & -0.031 & -0.093 & 0.123 & 0.142 \\
\hline Pimelodus atrobrunneus & -0.024 & -0.003 & -0.018 & 0.081 & -0.064 \\
\hline Pimelodus maculatus & 0.072 & -0.201 & -0.058 & 0.052 & -0.143 \\
\hline Rhamdia quelen & -0.195 & -0.075 & 0.336 & -0.122 & -0.080 \\
\hline Schizodon nasutus & -0.199 & 0.061 & -0.026 & -0.081 & -0.192 \\
\hline Steindachnerina spp. & 0.265 & -0.086 & -0.041 & -0.030 & -0.064 \\
\hline
\end{tabular}

disturbances, such as El Niño and La Niña, and regional ones, such as the South Atlantic Convergence Zone (SACZ) and the Convective Systems (CS), provide alternating flood and drought periods (Kousky \& Cavalcanti, 1984; Mendonça $\&$ Boratti, 2008), which could help to increase the richness and the abundance of larvae in the region.

Although the differences in environmental variables influence the abundance and composition of the ichthyoplankton among the reproductive periods, it was also observed some differences in larval assemblage composition among sections. When compared to Chapecó, the higher variability of the Ligeiro section suggests that, besides the influence of environmental variables, there is, for that section, a large contribution from the set-up and operational procedures of the Itá and Machadinho dams. Hence, four years after closing the dam, changes in the fish assemblage still occur inside the Itá reservoir. These results are similar to those found for adult fish captured in the same period in the dam's catchment area (Zaniboni-Filho et al., 2008). Similar to adult fish, the impact of dams in the ichthyoplanktonic community includes a reduction in larval abundance (Scheidegger \& Bain, 1995), the suppression of growth rates (Weisberg \& Burton, 1993), changes in the community structure (Bain et al., 1988) and a reduction in species diversity (Gehrke et al., 1995), clearly reflecting the impact of the dam in reproduction and recruitment (Agostinho et al., 2004a).

Although confined between the Itá and Machadinho dams, the sampling sites of the Ligeiro section show great significance as a reproduction area for most of the fish communities occurring in the Itá reservoir. According to Agostinho et al. (2007), most of the species that colonize the dams, including those that present plasticity to reproduction, seek for lateral tributaries, stretches upstream or even more lotic areas for reproduction.

This study showed that the mouths of tributaries are important reproduction and growth environments for fish in the upper Uruguay River region. Larval assemblages in these regions are composed mainly by species that perform short migrations. When comparing the three reproductive periods, a low abundance of larvae and number of taxa, an absence of individuals in post-flexion stages and a high dissimilarity in the larval assemblage structure was observed in the reproductive period with higher flow and lower water temperature. Spatially, there is a lower temporal variability in the larval assemblage structure in the free environment of the reservoir than in the impacted one.

\section{Acknowledgments}

The authors would like to thank the coworkers from LAPAD (CCA/UFSC) for their help in field sampling and sample processing. This work is part of the project "Monitoring and management of the ichthyofauna at Itá hydroelectric power station" (Monitoramento e manejo da Ictiofauna da UHE Itá), supported by TRACTEBEL ENERGIA, CAPES and CNPq.

\section{Literature Cited}

Agostinho, A. A., L. C. Gomes \& F. M. Pelicice. 2007. Ecologia e Manejo de Recursos Pesqueiros em Reservatórios do Brasil. Maringá, EDUEM, 501p. 
Agostinho, A. A., L. C. Gomes, S. Veríssimo \& E. K. Okada. 2004 b. Flood regime, dam regulation and fish in the Upper Paraná river: effects on assemblage attributes, reproduction and recruitment. Reviews in Fish Biology and Fisheries, 14: 11-19.

Agostinho, A. A., S. M. Thomaz \& L. C. Gomes. 2004a. Threats for biodiversity in the floodplain of the Upper Paraná River: effects of hydrological regulation by dams. Ecohydrology \& Hydrobiology, 4: 255-268.

Agostinho, A. A. \& M. Zalewski. 1995. The dependence of fish community structure and dynamics on floodplain and riparian ecotone zone in Paraná River, Brazil. Hydrobiologia, 303: 141-148.

Ahlstrom, E. H. \& H. G. Moser. 1976. Eggs and larvae of fishes and their role in systematic investigations and in fisheries. Revue des Travaux de L'Institut des Peches Maritimes, 40: 379-398.

Andrewartha, H. G. \& L. C. Birch. 1982. Selections from the Distribution and Abundance of Animals. Chicago, the University Chicago Press, 275p.

Bain, M. B., J. T. Finn \& H. E. Booke. 1988. Streamflow regulation and fish community structure. Ecology, 69: 382-392.

Bayley, P. B. 1973. Studies on the migratory Characin, Prochilodus platensis Holmberg, 1889 (Pisces, Charocoidei) in the River Pilcomayo, South America. Journal of Fish Biology, 5: 25-40.

Fuiman, L. A. 2002. Special Considerations of Fish Eggs and Larvae. Pp. 1-32. In: Fuiman, L. A. \& R. G. Werner (Eds.).Fishery Science. The unique contributions of early life stages. Oxford, Blackwell Publishing, 326p.

Gehrke, L. C., P. Brown, C. B. Schiller, D. B. Moffat \& A. M. Bruce. 1995. River regulation and fish communities in the Murray-Darling river system, Australia. Regulated Rivers: Research and Management, 11:363-375.

Hair, J. F., R. E. Anderson, L. Tatham \& B. J. Grablowski. 1984. Multivariate data analysis. New York, McMillan, 360p.

Hermes-Silva, S., D. A. Reynalte-Tataje \& E. Zaniboni-Filho. 2009. Spatial and temporal distribution of ichthyoplankton in the upper Uruguay river, Brazil. Brazilian Archives of Biology and Technology, 52: 933-944.

Hicks, C.R. 1993. Fundamental concepts in the design of experiments. $4^{\text {th }}$. Ed. Saunders College Publishing, New York, $384 p$.

Humphries, P. \& P. S. Lake. 2000. Fish larvae and the management of regulated rivers. Regulated Rivers: Research and Management, 16: 421-432.

Jackson, D. A. 1993. Stopping rules in principal components analysis: a comparison of heuristical and statistical approaches. Ecology, 74: 2204-2214.

Keckeis, H., E. Bauer-Nemeschkal, V. V. Menshutkin, H. L. Nemeschkal \& E. Kamler. 2000. Effects of female attributes and eggs properties on offspring viability in a rheophilic cyprinid, Chondrostoma nasus. Canadian Journal of Fisheries and Aquatic Sciences, 57: 789-796.

Kousky, V. E. \& I. F. Cavalcanti. 1984. Eventos El Niño - Oscilação Sul: características, evolução e anomalias de precipitação. Ciencias e Cultura, 36: 1188-1199.

Mendonça, R. W. B. \& J. P. Boratti. 2008. Estudo da energética modal para episódios de ZCAS. Parte II: Impacto da resolução do modelo e da parametrização de convecção. Revista Brasileira de Meteorologia, 23: 381-403.

Nakatani, K., A. A. Agostinho, G. Baumgartner, A. Bialetzki, P. V. Sanches, M. C. Makrakis \& C. S. Pavanelli. 2001. Ovos e larvas de peixes de água doce: desenvolvimento e manual de identificação. Maringá, EDUEM, 378p.
Nesler, T. P., R. T. Muth \& C. Wasowicz. 1988. Evidence for baseline flow spikes as spawning cues for Colorado squawfish in the Yampa River, Colorado. Transactions of the American Fisheries Society Symposium, 5: 68-79.

Oldani, N. O. 1990. Variaciones de la abundancia de peces del valle del rio Paraná (Argentina). Revista de Hydrobiologia Tropical, 23: 67-76.

Peters, R. K. 1986. The role of prediction in limnology. Limnology and Oceanography, 31: 1143-1159.

Petrere, M Jr. 1996. Fisheries in large tropical reservoirs in South América. Lakes \& Reservoirs: Research and Management, 2: 111-133.

Pickett, S. T. A. \& P. S. White 1985. The ecology of natural disturbance and patch dynamics. São Diego, Academic Press, $472 p$.

Poff, N. L. \& J. D. Allan. 1995. Functional organization of stream fish assemblage in relation to hydrological variability. Ecology, 76: 606-627.

Ponton, D. \& P. Vauchel. 1998. Immediate downstream effects of the Petit Saut dam on young neotropical fish in a large tributary of the Sinnamary river (French Guiana, South América). Regulated Rivers: Research \& Management, 14: 227-243.

Reynalte-Tataje, D. A., A. A. Agostinho, A. Bialetzki, S. HermesSilva, R. Fernandes \& E. Zaniboni-Filho. 2012. Spatial and temporal variation of the ichthyoplankton in a subtropical river in Brazil. Environmental Biology of Fishes, 94: 403-419.

Reynalte-Tataje, D. A., S. Hermes-Silva, P. A. Silva, A. Bialetzki \& E. Zaniboni-Filho. 2008. Locais de crescimento de larvas de peixes na região do alto rio Uruguai (Brasil). Pp. 159-194. In: Zaniboni-Filho, E. \& A. P. O. Nuñer (Eds.). Reservatório de Itá. Estudos ambientais, desenvolvimento de tecnologias de cultivo e conservação da ictiofauna, Florianópolis, Editora UFSC, 319p.

Reynalte-Tataje, D. A. \& E. Zaniboni-Filho. 2008. Biologia e identificação de ovos e larvas de peixes do alto rio Uruguai. Pp. 229256. In: Zaniboni-Filho, E. \& A. P. O. Nuñer (Eds.). Reservatório de Itá. Estudos ambientais, desenvolvimento de tecnologias de cultivo e conservação da ictiofauna, Florianópolis, Editora UFSC, 319p.

Sanches, P. V., K. Nakatani, A. Bialetzki, G. Baumgartner, L. C. Gomes \& E. A. Luiz. 2006. Flow regulation by dams affecting ichthyoplankton: the case of the Porto Primavera dam, Paraná River, Brazil. River Research and Applications, 22: 555-565.

Scheidegger, K. J. \& M. B. Bain. 1995. Larval fish distribution and microhabitat use in free-flowing and regulated rivers. Copeia, 1995: 125-135.

Sokal, R. R. \& F. J. Rohlf. 1981. Biometry: the principles and practice of statistics in biological research. São Francisco, W. H. Freeman, 859p.

Suzuki, H. I., C. K. Bulla, A. A. Agostinho \& L. C. Gomes. 2005. Estratégias reprodutivas de assembléias de peixes em reservatórios. Pp. 223-242. In: Rodrigues, L., S. M. Thomaz, A. A. Agostinho \& L. C. Gomes (Eds.). Biocenoses em Reservatórios. Padrões espaciais e temporais. São Carlos, RiMa, 257p.

Tanaka, S. 1973. Stock assessment by means of ichthyoplankton surveys. FAO Fisheries Technical Paper, 122: 33-51.

Thomaz, S. M., L. M. Bini \& R. L. Bozelli. 2007. Floods increase similarity among aquatic habitats in river-floodplain systems. Hydrobiologia, 579: 1-13.

Weisberg, S. B. \& W. H. Burton. 1993. Enhancement of fish feeding and growth after an increase in minimum flow below the Conowingo Dam. North American Journal of Fisheries Management, 13: 103-109. 
Welcomme, R. L. 1979. Fisheries ecology of floodplain rivers. London, Longman, 317p.

Werner, R. G. 2002. Habitat requirements. Pp. 161-82. In: Fuiman, L. A. \& R. G. Werner (Eds.). Fishery Science The Unique Contributions of Early Life Stages. Oxford, Blackwell Sciences, $326 \mathrm{p}$.

Wilkinson, L. 1998. Systat: The system for statistic. Evanston, IL, Systat Inc. 228p.

Witting, D. A., W. A. Kenneth \& M. P. Fahay. 1999. Larval fishes of a Middle Atlantic Bight estuary: assemblage structure and temporal stability. Canadian Journal of Fisheries and Aquatic Science, 56(2): 222-230.

Zaniboni-Filho, E., A. P. O. Nuñer, D. A. Reynalte-Tataje, S. Hermes-Silva \& S. Meurer. 2008. Alterações espaciais e temporais da estrutura da comunidade de peixes em decorrência da implantação do reservatório de Itá (alto rio Uruguay). Pp. 2148. In: Zaniboni-Filho, E. \& A. P. O. Nuñer (Eds.). Reservatório de Itá. Estudos ambientais, desenvolvimento de tecnologias de cultivo e conservação da ictiofauna, Florianópolis, Editora UFSC, 319p.

Zaniboni-Filho, E. \& U. H. Schulz. 2003. Migratory fishes of the Uruguay river. Pp. 135-168. In: Carolsfeld, J., B. Harvey, A. Baer \& C. Ross (Eds.). Migratory fishes of the South América: biology, social importance and conservation status. Victoria, World Fisheries Trust, 372p.

Submitted August 3, 2011 Accepted September 14, 2012 